\title{
ANNUAL MEETING OF THE BRITISH MEDICAL ASSOCIATION AT MANCHESTER
}

THE attention of readers of this Journal, and Members of the Medical Society for the Study of Venereal Diseases especially, is directed to the Annual Meeting of the British Medical Association, Manchester, on July 23rd, 24th, 25th, 26th. Although perhaps not even the most patriotic of Welshmen would claim that syphilis and gonorrhœa are unknown in the Principality, nevertheless the I928 Meeting in Cardiff was held without there being a Venereal Diseases Section. The Lancastrian is sometimes heard to boast that his county thinks a day ahead of the rest of England. Be that as it may, Lancashire certainly has, by taking thought, added two cubits to the stature of the Annual Meeting this year; for a Section of Venereal Diseases has not only been formed but has been allotted two whole days for its deliberations. The President and Officers of the Section sincerely hope that every venereologist in the country will not only make a special effort to attend the sessions on both days, but will also take an active part in the discussions arising out of the papers read. "Men are never," said Macaulay, "so likely to settle a question rightly as when they discuss it freely."

For the first time in the history of the Venereal Diseases Section, eminent foreign colleagues have been invited to read opening papers. Aldred Scott Warthin, Professor of Pathology in the University of Michigan; Svend Lomholt, of the Finsen Light Institute in Copenhagen; and Charles Levaditi, of the Pasteur Institute in Paris, will do so. The presence of such distinguished guests will be a great honour; and the most fitting way in which appreciation and welcome can be expressed is by the attendance of large audiences of their British fellow-workers.

\section{Venereal Diseases}

President: William CoATEs, C.B., C.B.E., F.R.C.S. Vice-Presidents : E. T. BuRKe, D.S.O., M.B., Ch.B. ; A. C. Roxburgh, M.D., M.R.C.P. ; David Watson, M.B., C.M. ; AleXander Wilson, F.R.C.S. 


\section{BRITISH JOURNAL OF VENEREAL DISEASES}

Honorary Secretaries: GoRdon WhiteHEAD, M.B., Ch.B., 6, St. Ann's Passage, Manchester ; E. R. TownLEY ClaRkSON, M.R.C.S., L.R.C.P., 43, Queen Anne Street, London, W. I.

The following provisional programme has been arranged :

Wednesday, July 24th.-Io a.m. Discussion: Lesions of Latent Syphilis (with lantern demonstration). To be opened by Professor A. S. WARThIN (Michigan), followed by Professor Carl H. Browning (Glasgow), Dr. H. M. Hanschell (London), and Sir Humphrey Rolleston (Cambridge).

Thursday, July 25th.-Io a.m. Discussion : Diagnostic and Other Errors in Questions of Venereal Disease. To be opened by Colonel L. W. HARRISON (London), followed by Mr. David Lees (Edinburgh) and Mrs. MarGARET RORKE (London).

Afternoon Session. Discussion. Different Bismuth Preparations in Therapy of Syphilis : Rate of Absorption as a Guide for their Employment. To be opened by Dr. Svend Lomholt (Copenhagen), followed by Professor C. Levaditi (Pasteur Institute, Paris), Dr. Morna L. RAWLines (London) and Mr. V. E. Lloyd.

\section{MEDICAL SOCIETY FOR THE STUDY OF VENEREAL DISEASES}

The Annual General Meeting of this Society will be held on Saturday, July I3th. Full particulars will be sent to members within a short time. 